\title{
PENGARUH PROMOSI DAN SERVICESCAPE TERHADAP KEPUTUSAN MENGINAP MELALUI CITRA MEREK DI EL- ROYALE HOTEL BANYUWANGI PADA MASA PANDEMI
}

\author{
Christina Natalia Putri Subroto ${ }^{1}$ \\ Theresia Pradiani ${ }^{2}$ \\ Fathorrahman $^{3}$
}

\author{
Program Magister Manajemen Institut Teknologi Bisnis dan Asia Malang, 1,2,3 \\ email: christinanataliaputri@gmail.com
}

\begin{abstract}
During this Pandemic Covid 19 situation, the competition in the hotel industry becomes more competitive. The niche market especially in this industry become smaller and tighter. Thus, the hotel businesses have to be more aware with all the factors than can affect the customer to do the purchase decision to keep their sustainability and to win the competition. Some of the important factors that can affect the consumer decision are promotion, servicescape and brand image. The study was conducted to find out the influence of promotion and servicescape of stay decisions through of brand image at El Royale Hotel Banyuwangi. This research uses a type of quantitive research with path analysis as the method. The tool that was used by the researcher is IBM SPSS 26. The population of this study is the visitors who stay at El Royale Hotel Banyuwangi, with the number of samples used are 100 based on Slovin Formula and taken by purposive sampling technique.The sampling's criteria that are used in this research are the guests above 17 years old, and the guest who act as a decision maker. The result of this study is show that (1) partially promotion and servicescape affect the brand image positively and significantly. (2) partially promotion, servicescape and brand image affect the stay decision positively and significantly. (3) Brand image able to mediate the influence of promotion to stay decision. (4) Brand image is not able to mediate the influence of servicescape to stay decision.
\end{abstract}

Keywords: promotion, serviesape, brand image, staydecision.

\section{PENDAHULUAN}

Seperti yang telah kita ketahui, pandemi covid 19 mulai merebak luas di seluruh pelosok dunia sejak akhir tahun 2019 hingga saat ini. Wabah ini telah melemahkan hampir seluruh lini bisnis di seluruh dunia, tanpa terkecuali di Indonesia. Banyak sekali sektor industri bisnis di Indonesia yang nyaris lumpuh akibat adanya wabah ini, salah satunya yaitu bisnis perhotelan. Industri perhotelan itu sendiri adalah salah satu industri yang turut berkontribusi dan berkaitan erat dengan industri pariwisata, dimana peran utama hotel dalam pariwisata adalah sebagai sarana akomodasi umum yang membantu para wisatawan untuk berwisata dengan jasa penginapan yang disediakan oleh hotel. Organisasi Pariwisata Duniapun telah menyatakan bahwa Hotel adalah salah satu sarana utama yang sangat penting dan saling berhubungan dengan pariwisata (main 
tourism superstructure), dimana ini berarti bahwa hidup dan kehidupan industri perhotelan banyak bergantung pada jumlah wisatawan yang datang, sedangkan pada saat ini, seperti yang telah kita ketahui, pasar utama wisatawan mancanegara Indonesia, seperti China, Singapura, dan Australia hingga kini masih memberlakukan penutupan penerbangan ke Indonesia akibat adanya pandemi, tak hanya itu, wisatawan domestikpun masih banyak yang ragu untuk datang ke tempat wisata dan berlibur. Kehidupan new normal yang sudah dicanangkan pemerintah yang digadang-gadang akan menjadikan harapan bagi pengusaha perhotelan tidak serta merta membuat usaha perhotelan menjadi bangkit secara drastis seperti sedia kala.

\section{Tabel Persentasi Tingkat Penghunian Kamar Bulanan Hotel Bintang 4 di Banyuwangi Februari - October 2019/2020}

\begin{tabular}{|c|c|c|c|c|c|c|c|c|c|c|c|c|c|c|c|c|c|c|c|}
\hline \multirow{2}{*}{ No } & \multirow{2}{*}{ Nama Hotel } & \multicolumn{2}{|c|}{ Feb } & \multicolumn{2}{|c|}{ Mar } & \multicolumn{2}{|c|}{ Apr } & \multicolumn{2}{|c|}{ Mei } & \multicolumn{2}{|c|}{ Jun } & \multicolumn{2}{|c|}{ Jul } & \multicolumn{2}{|c|}{ Agu } & \multicolumn{2}{|c|}{ Sep } & \multicolumn{2}{|c|}{ Okt } \\
\hline & & 2019 & 2020 & 2019 & 2020 & 2019 & 2020 & 2019 & 2020 & 2019 & 2020 & 2019 & 2020 & 2019 & 2020 & 2019 & 20202 & 2019 & 2020 \\
\hline 1 & El Royale Hotel Banyuwangi & 40.68 & 46.48 & 50.52 & 34.2 & 48.75 & 24.29 & 27.65 & 26.26 & 56.7 & 23.19 & 644.7 & 33.09 & 52.76 & 39.86 & 47.57 & 37.98 & 73.8 & 59.9 \\
\hline 2 & Ketapang Indah Hotel & 63.27 & 73.44 & 72.86 & 42.8 & 78.62 & & 48.82 & 0 & 69.7 & 19.61 & 88.2 & 37.49 & 87.57 & 52.21 & 84.57 & 54.92 & 76.9 & 54.24 \\
\hline 3 & Kokoon Hotel & $\mathrm{N} / \mathrm{A}$ & $\mathrm{N} / \mathrm{A}$ & $N / A$ & $N / A$ & $\mathrm{~N} / \mathrm{A}$ & 60.1 & $\mathrm{~N} / \mathrm{A}$ & 31.5 & $\mathrm{~N} / \mathrm{A}$ & 55.2 & $\mathrm{~N} / \mathrm{A}$ & 42.71 & $\mathrm{~N} / \mathrm{A}$ & 51.87 & $\mathrm{~N} / \mathrm{A}$ & 44.7 & $\mathrm{~N} / \mathrm{A}$ & 60.52 \\
\hline 4 & Aston Hotel & 65.48 & 76.84 & 75.64 & 44,64 & 66.99 & 3.1 & 44,14 & 0 & 59.7 & 27.8 & 83.84 & 42,33 & 78.63 & | $49.46 \mid$ & 71,44 & $48.97 \mid$ & 83.2 & 72.59 \\
\hline 5 & Dialoog Hotel & 44.11 & 51.37 & 64.26 & 33.57 & 57.27 & 2.1 & 26.09 & 2.56 & 43.7 & 5.75 & 67.46 & 15.49 & 64.21 & 33.87 & 59.71 & 20.14 & 67.3 & 26.89 \\
\hline
\end{tabular}

Sumber : Olah data Competitor Hotel Record El Hotel Royale banyuwangi September 2020

Tabel 1.1 diatas menunjukkan bahwa terdapat penurunan okupansi seluruh hotel bintang 4 di Banyuwangi akibat pandemi covid 19 ini. Persaingan hotel diyakini menjadi semakin kompetitif. Kolam market yang dulunya luas saat ini menjadi lebih sempit, oleh karena itu pelaku usaha perhotelan saat ini harus jeli dalam mengenali faktor-faktor apa saja yang dapat mempengaruhi konsumen untuk menginap, sehingga dari sini pelaku usaha dapat menentukan strategi yang paling baik dan tepat agar dapat mempengaruhi keputusan konsumen untuk membeli, tentunya dengan meningkatnya keputusan konsumen untuk menginap maka sebuah usaha dapat memenangkan persaingan dan menjaga kestabilan kelangsungan usaha terutama di masa pandemi ini. 
El Hotel Royale Banyuwangi adalah salah satu hotel berbintang 4 di Banyuwangi yang baru berdiri di tahun 2017. Hotel ini merupakan pioneer hotel bintang 4 di Banyuwangi yang berdiri dibawah naungan El grup international. El Hotel Royale Banyuwangi dikenal dengan sebutan MICE (Meeting, Incentive, Convention, Exhibition) Hotel pertama di Banyuwangi, karena hotel ini adalah hotel pertama di Banyuwangi yang dilengkapi dengan meeting ballroom yang sangat luas dan dapat menampung 1200 orang. Jumlah kamar yang dimiliki oleh El Hotel Royale Banyuwangi adalah 162 kamar dengan 5 tipe kamar, yaitu Deluxe, Deluxe Pool, Junior Suite, Villa dan Royale Suite. Fasilitas yang disediakan oleh hotel ini juga sangat lengkap dan sangat memanjakan konsumen.

Salah satu strategi marketing jasa yang penting dan dapat mempengaruhi keputusan pembelian terutama di masa pandemi ini adalah promosi, melalui promosi, perusahaan dapat menginformasikan produkproduk baru, membujuk dan mempengaruhi calon konsumen untuk membeli produk dari perusahaan tersebut. Pada masa pandemi ini, kegiatan promosi di El Royale Hotel Banyuwangi masih tetap berjalan, walaupun penekanan biaya juga turut dilakukan dikarenakan pendapatan yang berkurang dikarenakan adanya pandemi. Saat ini El Hotel Royale Banyuwangi memilih untuk melakukan promosi berbiaya ringan saja, misalnya melalui website, social media, telemarketing, travel agent (baik Online Travel agent seperti Booking.com, Traveloka, Agoda, Tiket.com, dll, maupun Offline travel agent) dan direct marketing (email blast, wa blast dan cold call) terhadap para member mereka. Promosi berbiaya fantastis seperti memasang baliho, iklan majalah, koran dan menyelenggaraan event untuk saat ini masih belum bisa dilakukan karena adanya keterbatasan biaya, namun diharapkan promosi-promosi yang dilakukan oleh El Royale Hotel Banyuwangi tetap bisa diterima oleh masyarakat dan dapat membuat masyarakat terbujuk untuk menginap. berangkat dari hal ini maka peneliti ingin mengkaji lebih dalam, apakah promosi-promosi yang telah dilakukan oleh El Hotel Royale Banyuwangi selama masa pandemi ini dapat mempengaruhi keputusan menginap masyarakat atau tidak, dan seberapa besarkah pengaruh yang dihasilkan terhadap keputusan menginap di El Hotel Royale Bayuwangi.

Selain promosi yang menarik, first impression dari sebuah hotel juga merupakan daya tarik penting yang dapat mempengaruhi konsumen untuk dapat memutuskan menginap. Harris dan Ezzeh (2018) menyatakan bahwa "secara umum, sebelum melakukan pembelian, khususnya pada produk jasa, biasanya calon customer akan melakukan evaluasi atau penilaian terlebih dahulu terhadap tanda-tanda yang dimiliki oleh suatu perusahaan, hal ini dilakukan untuk mengetahui kemampuan dan kualitas perusahaan, hal ini disebabkan jasa bersifat tidak berwujud, tidak dapat terlihat langsung, tidak dapat dicicipi,tidak dapat diraba, tidak dapat didengar ataupun tidak dapat dibawa sebelum dikonsumsi, oleh karena itu untuk mengurangi ketidakpastian yang disebabkan oleh ketidakberwujudan, maka pelanggan akan mencari bukti berwujud yang memberikan informasi 
dan kepercayaan akan jasa yang diterimanya".Salah satu tanda yang dimaksud pada kalimat tersebut yaitu servicescape. Servicescape dijelaskan oleh Aal dan Abas (2016) sebagai lingkungan fisik yang didalamnya meliputi pelayanan pada suatu fasilitas interior ataupun eksterior. Hal ini dapat dpat saja meliputi desain interior, desain eksterior, simbol, tempat parkir, peralatan yang disediakan, denah layout, kualitas udara ataupun suhu udara yang ada pada fasilitas tersebut. Servicescape yang unik dan terencana seperti halnya desain lantai yang bermotif gajah oling, lobi yang berbentuk seperti pendapa, suguhan desain interior tradisional yang dilengkapi oleh patung-patung khas Banyuwangi dan lukisan Banyuwangi, kolam renang khusus anak, balkon pribadi disetiap kamar hingga lift yang diletakkan disetiap sudut hotel telah disediakan oleh El Hotel Royale Banyuwangi untuk menarik perhatian para calon konsumen, diharapkan servicescape yang menjadi pembeda dengan hotel-hotel pesaing ini juga turut mempengaruhi calon konsumen terbidik untuk mau memutuskan menginap di El Hotel Royale Banyuwangi, oleh karena itulah berdasarkan hal ini maka peneliti ingin mengkaji lebih dalam apakah servicescape yang sudah disediakan oleh El Hotel Royale Banyuwangi ini turut berpengaruh terhadap keputusan menginap.

Selain promosi dan servicescape, dalam setiap usaha, baik itu usaha yang bergerak dibidang barang maupun jasa, citra merek juga ikut andil dalam setiap pengambilan keputusan pembelian konsumen. Menurut Kotler dan Armstrong (2000:282), menempatkan merek dengan baik dalam benak konsumen merupakan salah satu kemampuan utama yang harus dimiliki oleh para pemasar terutama pada saat ini. Membuat citra merk berkembang kuat dan berada dalam benak konsumen adalah salah satu cara untuk dapat membuat konsumen mengenal produk tersebut, dan hal tersebut akan mempengaruhi perilaku konsumen dalam menentukan pilihan. Berkaitan dengan citra merek, El Grup sendiri sudah dikenal oleh masyarakat sebagai perusahaan manajemen hotel profesional dengan desain terbaik di kelasnya, memiliki keunikan gaya arsitektur yang berbeda dengan hotel sejenis lainnya di Banyuwangi, satusatunya hotel MICE di Banyuwangi yang berkonsep resort, hotel yang memiliki tema kebudayaan Banyuwangi dan hotel yang cocok untuk dikunjungi oleh keluarga, hal ini seharusnya cukup untuk menjadi poin plus tersendiri dan membuat El Hotel Royale memiliki citra yang baik dimata masyarakat, dan tentunya untuk memastikan bahwa citra hotel telah diterima dengan baik oleh konsumen maka perlu dilakukan pengkajian lebih lanjut.

\section{Rumusan Masalah}

Berdasarkan latar belakang diatas, maka rumusan masalah pada penelitian ini adalah untuk mengetahui apakah promosi dan servicescape secara parsial berpengaruh positif dan signifikan terhadap citra merek dan apakah promosi, servicescape dan citra merek berpengaruh positif dan signifikan terhadap keputusan menginap, serta mengetahui apakah citra merek mampu memediasi pengaruh antara promosi dan servicescape terhadap keputusan menginap. 


\section{Tujuan Penelitian}

Tujuan penelitian yang hendak dicapai pada penelitian ini adalah untuk mengetahui apakah terdapat pengaruh yang positif dan signifikan antara promosi, dan servicescape terhadap keputusan menginap melalui citra merek di EL Royale Hotel Banyuwangi pada masa pandemic

\section{TINJAUAN PUSTAKA Promosi}

Menurut Tjiptono (2010:45), promosi merupakan salah satu alat suatu perusahaan untuk dapat memperkenalkan suatu produk barang dan jasa yang baru, serta memperkuat brand image suatu produk yang telah ada sebelumnya, sedangkan Mursid dalam bukunya (2014:95) juga turut berpendapat bahwa promosi adalah tindakan komunikasi persuasif, mengajak, mendesak, membujuk, dan meyakinkan. Kotler dan Armstrong (2000) dalam bukunya turut menyimpulkan setidaknya ada 5 indikator promosi dalam pemasaran jasa, yaitu

1. Advertising/periklanan.

2. Sales promotion/ promosi penjualan.

3. Public relation/ hubungan masyarakat.

4. Personal selling/ penjualan personal.

5. Direct marketing/ pemasaran langsung.

\section{Servicescape}

Pada Jurnalnya, Bitner (1992) mencetuskan adanya servicescape, menurutnya servicescape adalah lingkungan fisik yang didalamnnya mencakup pelayanan pada suatu fasilitas interior ataupun fasilitas di eksteriornya. Pelayanan tersebut meliputi penilaian terhadap interior desain, desain exterior, simbol, tempat parkir, peralatan yang disediakan, denah layout, kualitas udara ataupun suhu udara yang ada pada fasilitas tersebut, sedangkan menurut Rambat Lupiyoadi (2013:120) servicescape adalah lingkungan fisik perusahaan tempat jasa diciptakan dan tempat penyedia jasa dan konsumen berinteraksi, ditambah unsur berwujud apapun yang digunakan untuk mengkomunikasikan atau mendukung peranan jasa itu. Berikut adalah 4 indikator yang dikemukakan oleh Aal \& Abas (2016) :

1. Ambient condition / Kondisi Lingkungan Sekitar

2. Spatial layout / Rencana Tata Ruang

3. Facility Aesthetic / Estetika Fasilitas

4. Sign and Symbol / Petunjuk dan Simbol

\section{Citra Merek}

Menurut Kotler dan Keller (2016), citra merek adalah pandangan konsumen terhadap sebuah merek sebagai refleksi dari asosiasi yang ada pada pikiran mereka. Citra merek itu sendiri adalah sebuah anggapan yang muncul dalam benak konsumen ketika mengingat suatu merek tertentu, sedangkan menurut Tjiptono (2005:49), citra merek adalah deskripsi asosiasi dan keyakinan konsumen terhadap sebuah merek, citra merek adalah pengamatan dan kepercayaan yang digenggam konsumen, seperti yang dicerminkan di asosiasi atau di ingatan konsumen. Keller (2013) menyatakan bahwa citra merek yang positif dapat terdiri dari 3 indikator, yaitu:

1. Strength of Brand Assocation/ kekuatan asosiasi merek.

2. Favorability of Brand Association/ keuntungan asosiasi merek . 
3. Uniqueness of Brand Association/ keunikan asosiasi merek

\section{Keputusan pembelian}

Menurut Fandy Tjiptono (2014:21) keputusan pembelian adalah proses dimana konsumen mengetahui atau mengenal masalah yang dimiliki, kemudian mencari informasi mengenai produk atau merek tertentu dan mengevaluasi seberapa baik masing-masing alternatif tersebut dapat memecahkan masalahnya, yang kemudian mengarah kepada keputusan pembelian. Selanjutnya, keputusan pembelian menurut Kotler dan Armstrong (2000:181) adalah membeli merek yang paling disukai, tetapi dua faktor bisa berada antara niat pembelian dan keputusan pembelian. Philip Kotler (2000:204) menggambarkan adanya lima tahapan keputusan pembelian yang pada kemudian dijadikan oleh peneliti sebagai indikator keputusan pembelian pada penelitian ini, yaitu :

1. Identifikasi Masalah

2. Pencarian informasi

3. Alternatif evaluasi

4. Keputusan pembelian,

5. Perilaku pasca pembelian.

Kerangka Konsep \& Hipotesis

Berikut kerangka konsep pada penelitian ini.

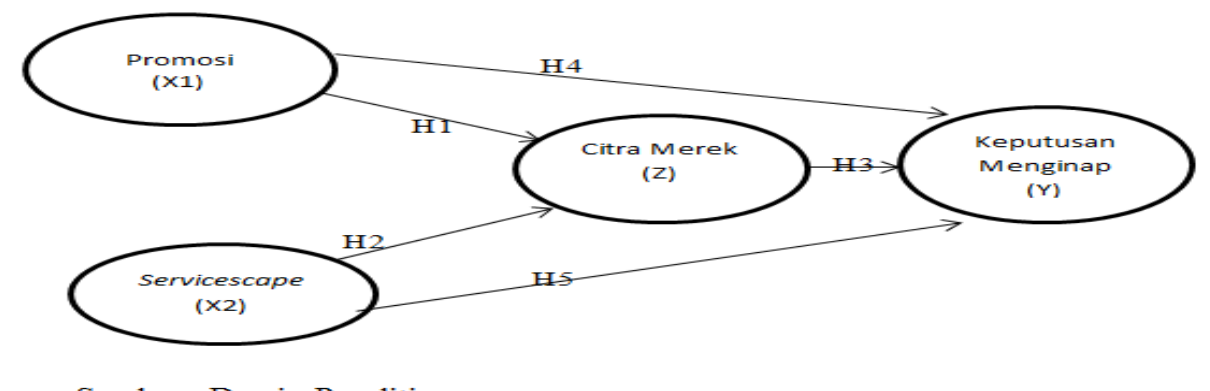

Gambar 1

Kerangka Konsep Penelitian

\section{Hipotesis Penelitian}

Berdasarkan rumusan masalah di atas dapat diajukan hipotesis sebagai berikut :

$$
\begin{aligned}
\mathrm{H}_{1}= & \text { Promosi berpengaruh positif } \\
& \text { dan signifikan terhadap citra } \\
& \text { merek di El Royale Hotel } \\
& \text { Banyuwangi pada masa } \\
\text { pandemi } & \\
\mathrm{H}_{2}= & \text { Servicescape berpengaruh } \\
& \text { positif dan signifikan terhadap } \\
& \text { citra merek di El Royale Hotel } \\
& \text { Banyuwangi pada masa } \\
& \text { pandemi } \\
\mathrm{H}_{3}= & \text { Citra merek berpengaruh } \\
& \text { positif dan signifikan terhadap } \\
& \text { keputusan menginap di EL }
\end{aligned}
$$

Royale Hotel Banyuwangi pada masa pandemi

$\mathrm{H}_{4}=$ Promosi berpengaruh positif dan signifikan terhadap keputusan menginap di El Royale Hotel Banyuwangi pada masa pandemi

$\mathrm{H}_{5}=$ Servicescape berpengaruh positif dan signifikan terhadap keputusan menginap di El Royale Hotel Banyuwangi pada masa pandemi

$\mathrm{H}_{6}=$ Citra merek mampu memediasi pengaruh promosi terhadap keputusan menginap di El Royale Hotel Banyuwangi pada masa pandemi 
Journal of Applied Management and Accounting Science. (JAMAS)

(Ardianto, Indra Prasetyo, Mei Indrawati 28 - 47)

Vol 3, No 1, Desember 2021

$\begin{aligned} \mathrm{H}_{7}= & \text { Citra merek mampu } \\ & \text { memediasi } \\ & \text { servicescape } \quad \text { tengaruh } \\ & \text { keputusan menginap di El } \\ & \text { Royale Hotel Banyuwangi } \\ & \text { pada masa pandemic }\end{aligned}$

\section{METODE PENELITIAN}

1. Lokasi dan Objek Penelitian

Lokasi pada penlitian ini adalah El Hotel Royale Banyuwangi yang beralamatkan di Jl. Raya jember KM 7 Pakistaji, Dusun Krajan, Dadapan, Kecamatan Kabat, Kabupaten Banyuwangi, Jawa Timur, sedangkan Objek pada penelitian ini adalah tamu yang menginap di El Hotel Royale Banyuwangi yang menginap di tanggal 15 hingga 24 Maret 2021 yang berjumlah 100 orang.

2. Definisi Operasional Variabel

Penelitian ini menggunakan 2 variabel bebas (X1\& X2), 1 variabel intervening $(\mathrm{Z})$ dan 1 variabel terikat (Y), yaitu :

1) Variabel promosi (X1) yang diukur dengan 3 indikator, yaitu advertising/periklanan, sales promotion/ promosi penjualan, dan direct marketing/ pemasaran langsung.

2) Variabel servicescape (X2) yang diukur dengan 4 indikator, yaitu ambient condition/kondisi

lingkungan, spatial layout/tata rencana ruang, aesthetic facilities/ estetika fasilitas, sign and symbol/tanda dan symbol

3) Variabel citra merek (Z) yang diukur dengan 3 indikator, yaitu: strength of brand association/ kekuatan asosiasi merek, favorability

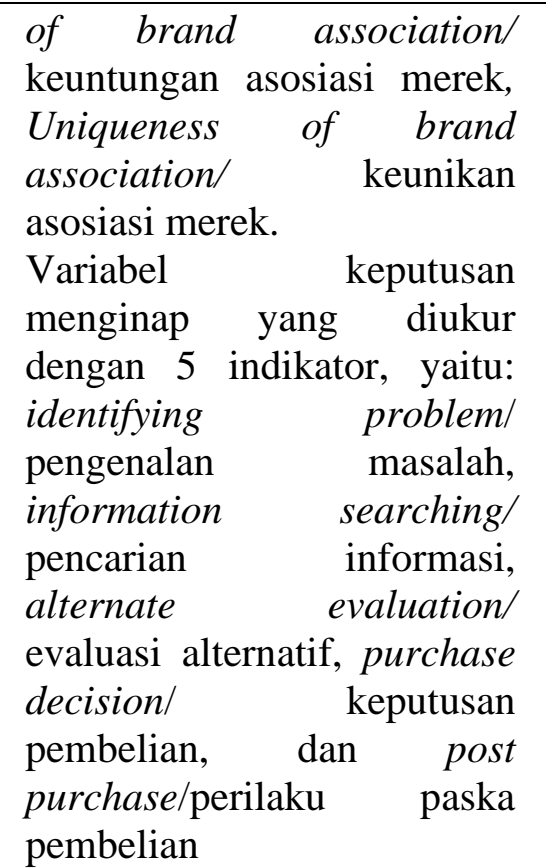

Teknik Pengumpulan dan Analisis Data

Teknik pengumpulan data pada penelitian ini menggunakan teknik angket (kuisioner) dengan skala likert, yang diberikan kepada 100 responden yang dipilih menggunakan teknik purposive sampling dengan ketentuan berumur 17 tahun keatas dan merupakan pengambil keputusan untuk menginap di El Royale Hotel Banyuwangi. Teknik analisis data yang digunakan adalah teknik analisa jalur yang dalam pengolahannya menggunakan bantuan program SPSS versi 26.

HASIL DAN PEMBAHASAN

Hasil Analisis

Hasil Uji Validitas dan Reliabilitas

Hasil uji menunjukkan bahwa keseluruhan butir pernyataan memiliki corrected item-total correlation ( $\mathrm{r}$ hitung) $>\mathrm{r}$ tabel pada taraf signifikansi 5\% (dimana pada akhirnya di dapatkan $\mathrm{r}$ tabel= 0,195), hal ini berarti seluruh pernyataan dalam penelitian ini 
dinyatakan valid. Hasil pengujian reliabilitas variabel pada pelitian ini sebagaimana ditunjukkan dalam tabel dibawah menunjukkan bahwa koefisien cronbach alpha masing- masing variabel lebih besar dari 0,60 , sehingga dapat dikatakan seluruh variabel yang membentuk model penelitian ini adalah reliable.

Tabel 2

Uji Reliability Instrumen Penelitian

\begin{tabular}{llll}
\hline No & Variabel & Cronbach Alpha & Keterangan \\
\hline 1 & Promosi (X1) & 0,801 & Reliabel \\
2 & Servicescape $(\mathrm{X} 2)$ & 0,872 & Reliabel \\
3 & Citra Merek (Z) & 0,896 & Reliabel \\
4 & Keputusan Menginap (Y) & 0,893 & Reliabel \\
\hline
\end{tabular}

Sumber: Olah data SPSS

\section{Hasil Uji Asumsi Klasik}

Berikut adalah hasil uji asumsi klasik pada penelitian ini.

1. Uji Normalitas

Untuk mendeteksi normalitas dalam suatu penelitian dapat dilakukan dengan menggunakan pengujian one sample Kolmogorov Smirnov. , jika nilai signifikansi dari hasil uji Kolmogorov Smirnof $>0.05$, maka asumsi normalitas terpenuhi. Berikut hasil uji one sample Kolmogorv Smirnov pada penelitian ini.

Tabel 3

Uji one sample Kolmogorov-Smirnov

\begin{tabular}{ll}
\hline Residual & Signifikansi \\
\hline Model 1 & 0.118 \\
Model 2 & 0.056
\end{tabular}

Sumber : Olah data SPSS

Dari tabel diatas diketahui bahwa signifikansi dari masing-masing model adalah 0,118 dan 0,055 , hal ini berarti signifikansi masingmasing model > 0,05, dan dari pengujian ini berarti dapat dibuktikan bahwa model regresi memenuhi asumsi normalitas atau dengan kata lain data berdistribusi normal.
2. Uji Multikolinieritas

Salah satu metode yang digunakan dalam menguji ada tidaknya multikolinieritas adalah dengan menggunakan Variance Inflation Factor (VIF). Apabila nilai VIF > 10 maka menunjukkan adanya multikolinieritas. Dan apabila sebaliknya VIF < 10 maka tidak terjadi multikolinieritas. Adapun hasil pengujian multikolinieritas pada penelitian ini, dapat dilihat pada tabel dibawah ini : 
Journal of Applied Management and Accounting Science. (JAMAS)

(Ardianto, Indra Prasetyo, Mei Indrawati 28 - 47)

Vol 3, No 1, Desember 2021

\section{Tabel 4}

Uji Multikolinieritas Dengan VIF

\begin{tabular}{ccccc}
\hline \multirow{2}{*}{ Variabel } & \multicolumn{2}{c}{ Model 1 } & \multicolumn{3}{c}{ Model 2 } \\
\cline { 2 - 5 } & Tolerance & VIF & Tolerance & VIF \\
\hline X1 (Promosi) & 0.982 & 1.019 & 0.893 & 1.12 \\
X2 (Servicescape) & 0.982 & 1.019 & 0.696 & 1.436 \\
Z (citra merek) & & & 0.635 & 1.574 \\
\hline
\end{tabular}

Sumber : olah data SPSS

Berdasarkan tabel 5.11 di atas didapatkan bahwa semua nilai VIF dari masing-masing variabel bebas baik pada model1 dan model 2 adalah kurang dari 10 dengan nilai tolerance lebih dari 0.1 , yang artinya antar variabel bebas tidak terdapat korelasi yang cukup kuat atau tidak terdapat multikolinieritas (asumsi terpenuhi).

3. Uji Heteroskedastisitas
Menurut Ghozali (2006: 142) salah satu cara untuk mendeteksi ada tidaknya heteroskedastisitas adalah dengan melakukan uji Glejser. Uji Glejser mengusulkan untuk meregres nilai absolut residual terhadap variabel independen. Hasil probabilitas dikatakan signifikan jika nilai signifikansinya diatas tingkat kepercayaan 5\%. Berikut hasil pengujian Glejser pada penelitian ini

Tabel 5

Uji heterokedastisitas dengan Glejser

\begin{tabular}{ccc}
\hline \multirow{2}{*}{ Variabel } & \multicolumn{2}{c}{ p-value } \\
\cline { 2 - 3 } & Model 1 & Model 2 \\
\hline X1 (Promosi) & 0.633 & 0.152 \\
X2 (Servicescape) & 0.293 & 0.051 \\
Z (citra merek) & & 0.131 \\
\hline
\end{tabular}

Sumber : Olah data SPSS

Dari hasil pengujian, didapatkan bahwa nilai signifikansi $\mathrm{p}$ value masing-masing variabel pada model 1 dan 2 menunjukkan angka $>0,05$, hal ini mengindikasikan bahwa tidak terjadi gejala heteroskedastisitas (asumsi terpenuhi).

\section{Uji Linieritas}

Hubungan kedua variabel dikatakan linier apabila nilai signifikansi uji linearity lebih kecil dari $\alpha 5 \%$, dan nilai signifikansi uji deviation from linearity lebih besar dari $\alpha$ 5\%. Hasil pengujian disajikan sebagai berikut. 


\begin{tabular}{lll} 
& \multicolumn{2}{c}{ Tabel 6 } \\
Hasil Pengujian Linieritas \\
\hline Variabel & Linerity & Deviation from linearity \\
\hline X1 dengan Z & 0.001 & 0.86 \\
X2 dengan Z & 0 & 0.214 \\
X1 dengan Y & 0 & 0.816 \\
X2 dengan Y & 0 & 0.084 \\
Z dengan Y & 0 & 0.113 \\
\hline
\end{tabular}

Sumber : Olah data SPSS

Pengujian asumsi linieritas pada tabel 5.14 didapatkan bahwa nilai signifikansi masing-masing pasangan uji linearity lebih kecil dari 0.05 , dan nilai signifikansi masing-masing pasangan uji deviation from linearity lebih besar dari 0.05. Sehingga dapat disimpulkan bahwa asumsi linieritas terpenuhi.

\section{Analisis Path}

1. Analisis Substruktur 1 (Pengaruh X1, dan X2 terhadap Z)

Hasil uji regresi standardize pada model 1 dapat ditunjukkan pada tabel di bawah ini:

Tabel 7

Hasil Analisis Regresi Substruktur 1

\begin{tabular}{lllll}
\hline Variabel & Beta & T & p-value t & Keterangan \\
\hline X1 (Promosi) & 0.254 & 3.104 & 0.002 & Signifikan \\
X2 (Servicescape) & 0.515 & 6.305 & 0.000 & Signifikan \\
& $=$ & 1.985 & & \\
$\mathrm{t}(0.05,97)$ & $=$ & 0.365 & & \\
\hline
\end{tabular}

Sumber : Olah data SPSS

Berdasarkan tabel di atas, dapat disimpulkan bahwa nilai $\mathrm{R}$ Square menunjukkan nilai sebesar 0.365 atau $36.5 \%$ yang artinya adalah variabel $\mathrm{Z}$ (Citra merek) dapat dijelaskan oleh variabel X1 (Promosi), dan X2 (Servicescape) sebesar $36.5 \%$, sedangkan sisanya sebesar $63.5 \%$ dipengaruhi oleh variabel di luar variabel bebas yang diteliti, dan berdasarkan hasil analisis tersebut, maka didapatkan persamaan regresi standardize pada substruktur 1 sebagai berikut:

$\mathrm{Z}=0.254 \mathrm{X} 1+0.515 \mathrm{X} 2+\varepsilon_{\mathrm{i}}$
Dari nilai $t_{\text {hitung juga menunjukkan }}$ bahwa:

1) Variabel $X 1$ (Promosi) memiliki nilai t hitung yang lebih besar dari $\mathrm{t}$ tabel $(3.104>1.985)$ atau nilai $\mathrm{p}$ value $\mathrm{t}$ lebih kecil dari $\alpha(0.002<$ 0.050) maka variabel $\mathrm{X} 1$ (Promosi) berpengaruh positif dan signifikan terhadap variabel $\mathrm{Z}$ (Citra merek). Koefisien yang positif menunjukkan bahwa peningkatan variabel X1 dapat secara signifikan meningkatkan variabel $\mathrm{Z}$.

2) Variabel $X 2 \quad$ (Servicescape) memiliki nilai $\mathrm{t}$ hitung yang lebih besar dari $t$ tabel $(6.305>1.985)$ 
atau nilai $\mathrm{p}$-value $\mathrm{t}$ lebih kecil dari $\alpha(0.000<0.050)$ maka variabel $\mathrm{X} 2$ (Servicescape) berpengaruh positif dan signifikan terhadap variabel Z (Citra merek). Koefisien yang positif menunjukkan bahwa peningkatan variabel $\mathrm{X} 2$ dapat secara signifikan meningkatkan variabel $\mathrm{Z}$.

2. Analisis Substruktur 2 (Pengaruh X1, X2, dan $\mathrm{Z}$ terhadap Y)

Hasil uji regresi standardize pada model 2 dapat ditunjukkan pada tabel di bawah ini:

Tabel 8

Hasil Analisis Regresi Substruktur 2

\begin{tabular}{lllll}
\hline Variabel & Beta & T & Sig t & Keterangan \\
\hline X1 (Promosi) & 0.137 & 2.292 & 0.024 & Signifikan \\
X2 & & & & Signifikan \\
(Servicescape) & 0.316 & 4.681 & 0.000 & Signifin \\
Z (Citra & 0.564 & 7.967 & 0.000 & Signifikan \\
merek) & & & & \\
$t_{(0.05,110)}$ & $=$ & 1.985 & & \\
R Square & $=$ & 0.694 & & \\
\hline
\end{tabular}

Sumber : Olah data SPSS

Berdasarkan tabel 7 di atas dapat disimpulkan bahwa nilai R Square menunjukkan nilai sebesar 0.694 atau $69.4 \%$ dimana artinya adalah variabel Y (Keputusan menginap) dapat dijelaskan oleh variabel X1 (Promosi), X2 (Servicescape), dan $\mathrm{Z}$ (Citra merek) sebesar $69.4 \%$, sedangkan sisanya sebesar $30.6 \%$ dipengaruhi oleh variabel di luar variabel bebas yang diteliti, dan berdasarkan analisis tersebut maka didapatkan persamaan regresi standardize substruktur 2 sebagai berikut:

$\mathrm{Y}=0.137 \mathrm{X} 1+0.316 \mathrm{X} 2+0.564$ $\mathrm{Z}+\varepsilon_{\mathrm{i}}$

Nilai $t$ hitung pada tabel menunjukkan bahwa:

1) Variabel $X 1 \quad$ (Promosi) memiliki nilai $t$ hitung yang lebih besar dari t tabel (2.292 > 1.985) atau nilai $p$-value $t$ lebih kecil dari $\alpha(0.024<0.050)$ maka variabel X1 (Promosi) berpengaruh positif dan signifikan terhadap variabel $\mathrm{Y}$ (Keputusan menginap). Koefisien yang positif menunjukkan bahwa variabel $\mathrm{X} 1$ dapat meningkatkan variabel Y secara signifikan.

2) Variabel $X 2$ (Servicescape) memiliki nilai $\mathrm{t}$ hitung yang lebih besar dari t tabel (4.681 > 1.985) atau nilai $\mathrm{p}$-value $\mathrm{t}$ lebih kecil dari $\alpha(0.000<0.050)$ maka variabel X2 (Servicescape) berpengaruh positif dan signifikan terhadap variabel Y (Keputusan menginap). Koefisien yang positif menunjukkan bahwa variabel X2 dapat meningkatkan variabel Y secara signifikan.

3) Variabel $Z$ (Citra merek) memiliki nilai $\mathrm{t}$ hitung yang lebih besar dari t tabel (7.967 > 1.985) atau nilai $p$-value $t$ lebih kecil dari $\alpha(0.000<0.050)$ maka variabel $\mathrm{Z}$ (Citra merek) 
Journal of Applied Management and Accounting Science. (JAMAS)

(Ardianto, Indra Prasetyo, Mei Indrawati 28 - 47)

Vol 3, No 1, Desember 2021

\begin{tabular}{lll}
\hline berpengaruh positif dan & dapat secara signifikan \\
signifikan terhadap variabel Y & & meningkatkan variabel Y. \\
(Keputusan menginap). & Dari kedua persamaan tersebut, \\
$\begin{array}{l}\text { Koefisien yang positif } \\
\text { menunjukkan bahwa variabel Z }\end{array}$ & maka diperoleh hasil analisis jalur \\
(path) secara keseluruhan adalah:
\end{tabular}

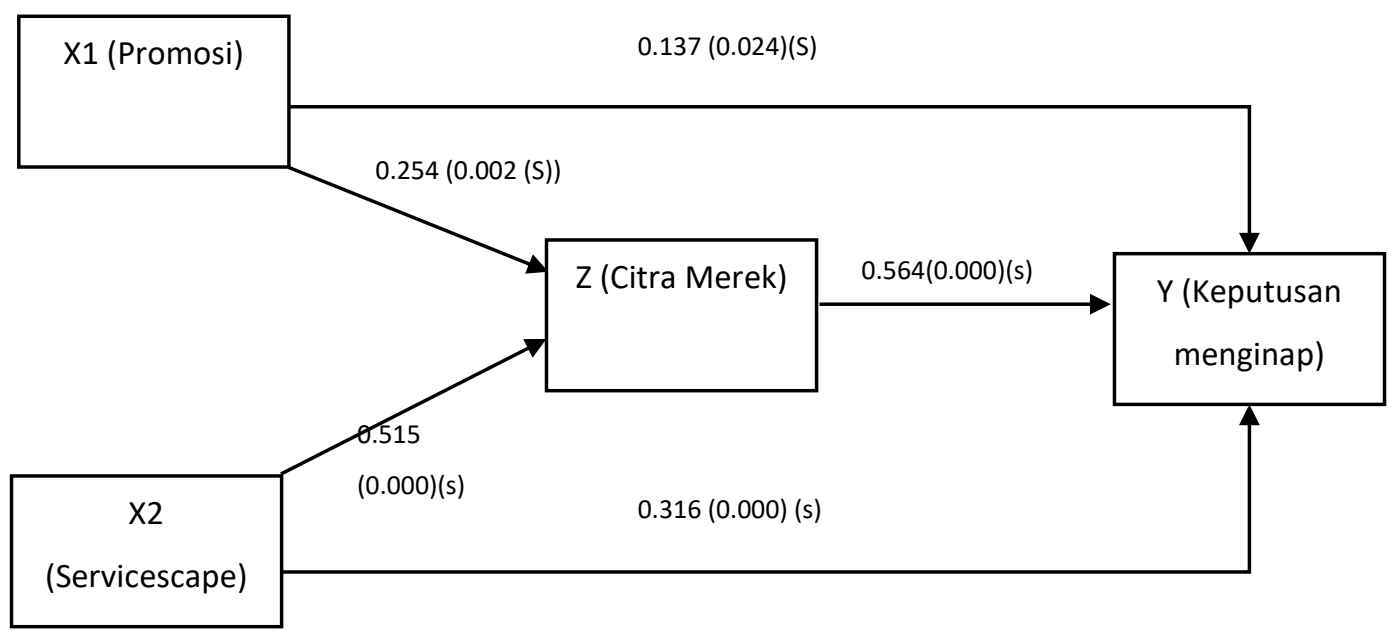

Gambar 2

Diagram Jalur dari Model Teoritis Penelitian (Direct Effect)

Dari gambar tersebut dan penjelasan sebelumnya, telah dilakukan pengujian Goodness of Fit model menggunakan koefisien determinasi total. Total keragaman data yang dapat dijelaskan oleh model diukur dengan rumus:

$\mathrm{R}_{\mathrm{m}}^{2}=1-\mathrm{P}_{\mathrm{e} 1}^{2} \mathrm{P}_{\mathrm{e} 2 \ldots .}^{2} \mathrm{P}_{\mathrm{ep}}$

Dimana

$\mathrm{P}^{2}{ }_{\mathrm{e} 1}=1-\mathrm{R}^{2}{ }_{1} ; \mathrm{P}^{2} \mathrm{e} 2=1-\mathrm{R}^{2}{ }_{2}$.

Dimana $\mathrm{R}^{2}{ }_{1}$ adalah $R$ square untuk persamaan 1 yaitu sebesar $0.365, \mathrm{R}_{2}^{2}$ adalah $R$ square untuk persamaan 2 yaitu sebesar 0.694 :

$\mathrm{P}_{\mathrm{e} 1}^{2}=1-0.365=0.635 ; \mathrm{P}_{\mathrm{e} 2}^{2}=1-$ $0.694=0.306$.

Sehingga diperoleh koefisien determinasi total adalah sebagai berikut:
$\mathrm{R}^{2}{ }_{\mathrm{m}}=1-(0.635 \times 0.306)=0.806$ atau $80.6 \%$

Hasil perhitungan $\quad \mathrm{R}^{2}{ }_{\mathrm{m}}$ mengindikasikan keragaman data yang dapat dijelaskan oleh model tersebut adalah sebesar 0.806 atau dengan kata lain informasi yang terkandung dalam data $80.6 \%$ dapat dijelaskan oleh model tersebut. Sedangkan $19.4 \%$ keragaman sisanya dijelaskan oleh variabel lain (yang belum terdapat di dalam model).

Secara keseluruhan, model pada penelitian ini terbagi atas 5 pengaruh langsung, dan 2 pengaruh tidak langsung. Tabel berikut menyajikan hasil pengujian pengaruh langsung dan pengaruh tidak langsung: 
Journal of Applied Management and Accounting Science. (JAMAS)

(Ardianto, Indra Prasetyo, Mei Indrawati 28 - 47)

Vol 3, No 1, Desember 2021

Tabel 9

Hasil Pengujian Hipotesis Pengaruh Langsung

\begin{tabular}{lllll}
\hline Variabel Bebas & Variabel Terikat & Path & p-value & Keterangan \\
\hline X1 & Z & 0.254 & 0.002 & Signifikan \\
X2 & Z & 0.515 & 0 & Signifikan \\
X1 & Y & 0.137 & 0.024 & Signifikan \\
X2 & Y & 0.316 & 0 & Signifikan \\
Z & Y & 0.564 & 0 & Signifikan \\
\hline
\end{tabular}

Sumber : Olah data Output SPSS

Tabel 10

Hasil Pengujian Hipotesis Pengaruh Tidak Langsung

\begin{tabular}{cccc}
\hline Variabel Bebas & Variabel Perantara & Variabel Terikat & Koefisien \\
\hline X1 & Z & Y & 0.143 \\
X2 & Z & Y & 0.29 \\
\hline
\end{tabular}

Sumber: Olah data Output SPSS

Hipotesis Pengaruh Tidak dari koefisien jalur hubungan Langsung langsung. Diketahui koefisien jalur 1) Pengaruh Promosi Terhadap pengaruh langsung promosi terhadap Keputusan Menginap Melalui keputusan menginap lebih kecil

\section{Citra Merek}

Pengaruh tidak langsung antara variabel Promosi terhadap variabel Keputusan menginap melalui variabel Citra merek, diperoleh dari hasil kali pengaruh langsung antara variabel promosi terhadap variabel citra merk dan pengaruh langsung antara variabel citra merek terhadap variabel keputusan menginap, sehingga besar pengaruh tidak langsung adalah 0.254 $\times 0.564=0.143$. Menurut Tony Wijaya (2009:149), suatu variabel dikatakan sebagai variabel intervening jika koefisien jalur hubungan tidak langsung lebih besar daripada koefisien jalur pengaruh tidak langsung promosi terhadap keputusan menginap melalui citra merek $(0,137<0,143)$ maka dapat diambil kesimpulan bahwa variabel Citra merek menjadi variabel mediasi pengaruh variabel Promosi terhadap Keputusan menginap.Kemampuan variabel citra merek untuk dapat memediasi antara variabel promosi dan keputusan menginap dapat dibuktikan dengan menggunakan uji sobel sebagai berikut:

Diketahui dari hasil analisis regresi substruktur 1 dan 2 sebagai berikut

Tabel 11

Nilai Unstandardized Coefficients Substruktur 1 (Dependent Variabel : Z Citra Merek) \& Substruktur 2 (Dependent Variabel : Y Keputusan Menginap)

\begin{tabular}{llll}
\hline Substruktur & Constant & B (Unstandardized Coefficients) & Std Error (Unstandardized Coefficient) \\
\hline 1 & X1 (Promosi) & 0.384 & 0.124 \\
2 & Z (Citra Merek) & 0.714 & 0.090 \\
\hline
\end{tabular}

Sumber : Olah data Output SPSS 
Sehingga dari tabel tersebut, maka dapat dihitung nilai $\mathrm{Z}$ hitung sebagai berikut :

Z hitung $=\frac{a b}{\sqrt{b^{2} S a^{2}+a^{2} S b^{2}}}$

$\mathrm{Z}$ hitung $=$

$\frac{0,384 \times 0,714}{\sqrt{\left(0,714^{2} 0,124^{2}\right)+\left(0,384^{2} 0,090^{2}\right)}}$

Z hitung $=2,885$

Dari hasil perhitungan sobel test di atas didapatkan nilai $\mathrm{z}$ sebesar 2.885 , karena nilai $\mathrm{z}$ yang diperoleh sebesar $2.885>1.96$ dengan tingkat signifikansi $5 \%$ maka hal ini membuktikan bahwa citra merek mampu memediasi pengaruh promosi terhadap keputusan menginap.

\section{2) Pengaruh Servicescape \\ Terhadap Keputusan Menginap \\ Melalui Citra Merek}

Pengaruh tidak langsung antara variabel Servicescape terhadap variabel keputusan menginap melalui variabel Citra merek, diperoleh dari hasil kali pengaruh langsung antara variabel Servicescape terhadap variabel citra merek dan pengaruh langsung antara variabel citra merek terhadap variabel keputusan menginap, sehingga besar pengaruh tidak langsung adalah $0.515 \times 0.564=$ 0.290, menurut Tony Wijaya (2009:149), suatu variabel dikatakan sebagai variabel intervening jika hubungan tidak langsung lebih besar dari hubungan langsung. Diketahui koefisien jalur pengaruh langsung servicescape terhadap keputusan menginap lebih besar daripada koefisien jalur pengaruh tidak langsung servicescape terhadap keputusan menginap melalui citra merek $(0,316>0,290)$, maka dapat diambil kesimpulan bahwa variabel citra merek bukan merupakan variabel mediasi pengaruh variabel servicescape terhadap keputusan menginap. Hal ini juga dapat dibuktikan dari uji sobel sebagai berikut:

Diketahui dari hasil analisis regresi substruktur 1 dan 2 sebagai berikut

Tabel 12

Nilai Unstandardized Coefficients Servicescape Substruktur 1 (Dependent Variabel : Z Citra Merek) dan Substruktur 2 (Dependent Variabel : Y Keputusan Menginap)

\begin{tabular}{lllll}
\hline Substuktur & Constant & $\begin{array}{l}\text { B } \begin{array}{c}\text { (Unstandardized } \\
\text { Coefficients) }\end{array} \\
\text { X2 (Servicescape) }\end{array}$ & $\begin{array}{l}\text { Std Error } \\
\text { Coefficient) }\end{array}$ & (Unstandardized \\
\hline 1 & 0.121 & 0.076 & \\
2 & $\mathrm{Z}$ (Citra Merek) & 0.714 & 0.090 \\
\hline
\end{tabular}

Sumber : Olah data Output SPSS

Sehingga dari kedua tabel tersebut, maka dapat dihitung nilai $\mathrm{Z}$ hitung sebagai berikut :

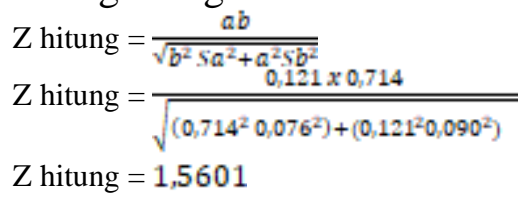

Dari hasil perhitungan sobel test di atas didapatkan nilai $\mathrm{z}$ sebesar 1,5601 , karena nilai z yang diperoleh sebesar $1,560<1.96$ dengan tingkat signifikansi $5 \%$ maka hal ini membuktikan bahwa citra merek tidak memediasi pengaruh servicescape terhadap keputusan menginap di EL Royale Hotel Banyuwangi. 


\section{Pembahasan}

\section{Pengaruh Variabel Promosi (X1) Terhadap Citra Merek (Z)}

Dari hasil uji hipotesis (uji t) yang dilakukan pada penelitian ini, maka diketahui bahwa variabel promosi berpengaruh secara positif dan signifikan terhadap citra merek. Hasil penelitian ini memperkuat penelitian yang sudah dilakukan oleh Oktavianty Tampubolon pada tahun 2015 yang membuktikan bahwa promosi memberikan pengaruh terhadap citra hotel, dan teori yang diungkapkan oleh Huriyati (2005:58) dalam bukunya, dimana beliau mengatakan bahwa salah satu tujuan promosi adalah untuk membangun citra perusahaan, semakin baik bentuk, penyampaian dam pengaplikasian promosi, maka semakin baik pula citra perusahaan yang akan dibentuk oleh masyarakat. Tentunya diharapkan semakain banyak variasi promosi yang dilakukan oleh El Royae Hotel Bayuwangi maka akan semakin banyak masyarakat yang mengetahui akan keberadaan hotel dan akan semakin kuat pula posisi brand di benak masyarakat luas.

2. Pengaruh Variabel Servicescape (X2) Terhadap Citra Merek (Z)

Dari hasil uji hipotesis yang dilakukan pada penelitian ini, diketahui bahwa variabel servicescape berpengaruh secara positif dan signifikan terhadap citra merek, tentunya hal ini selaras dengan teori yang telah dinyatakan oleh Bitner (1992) yang menyatakan bahwa lingkungan fisik memiliki kemampuan untuk mempengaruhi perilaku dan menciptakan image, khususnya pada bisnis jasa.
Kredibilitas sebuah perusahaan dapat dilihat pula dari lingkungan fisik yang ditawarkan oleh sebuah perusahaan kepada konsumennya. Hasil penelitian ini juga sejalan dengan penelitian yang telah dilakukan oleh Fadia Ayunisa (2016), dalam penelitianya disebutkan bahwa physical servicescape memiliki pengaruh terhadap hotel image atau citra hotel. Hasil penelitian ini turut menunjukkan bahwa estetika fasilitas hotel yang unik yang telah disediakan oleh hotel ternyata dapat mengangkat citra yang memang sengaja dibangun oleh El Royale Hotel Banyuwangi yaitu hotel yang lekat dengan kebudayaan Banyuwangi.

3. Pengaruh Variabel Citra Merek (Z) Terhadap Keputusan Menginap (Y)

Dari hasil uji hipotesis pada penelitian ini, diketahui bahwa variabel citra merek berpengaruh positif dan signifikan terhadap keputusan menginap, ini dapat dibuktikan dari adanya nilai positif pada nilai koefisien jalur yaitu sebesar 0,564, serta nilai t hitung $(7,967)$ yang lebih besar dari $t$ tabel (1,985) dan juga nilai signifikansi p value sebesar 0,000 yang kurang dari alpha yaitu 0,05 , Hal ini berarti sama dengan teori yang telah diungkapkan oleh Kotler dan Armstrong (2000:282) bahwa menempatkan merek dengan baik dalam benak konsumennya merupakan suatu kemampuan utama yang harus dimiliki oleh para pemasar. Memperkuat citra merek adalah salah satu cara untuk membuat konsumen dapat mengenal produk tersebut, dan hal tersebut akan 


\begin{abstract}
berpengaruh terhadap perilaku konsumen dalam menentukan pilihan. Beberapa penelitian terdahulu yang turut menguatkan teori ini adalah penelitian yang dilakukan oleh Jumiati, Sudarwati dan Tjong Su Lim dan Anton Widio Pratomo (2020), serta Handy Sudhiartha Athar (2020). Mereka menyebutkan dalam hasil penelitiannya bahwa citra merek berpengaruh secara positif dan signifikan terhadap keputusan menginap. Hubungan positif dan signifikan antara citra merek dengan keputusan menginap dapat tercermin dari adanya keunggulan yang dimiliki oleh El Royale Hotel Banyuwangi yang dapat membuat tamu puas untuk menginap. Adanya tema budaya Banyuwangi yang tersirat dalam interior hotel yang tentunya merupakan salah satu kekuatan dari hotel ini membuat tamu yang menginap senang hingga akhirnya mereka puas telah memutuskan untuk menginap di EL Royale Hotel Banyuwangi.
\end{abstract}

4. Pengaruh Variabel Promosi (X1) Terhadap Keputusan Menginap (Y)

Dari hasil pengujian hipotesis (uji t), diketahui bahwa pada penelitian ini variabel promosi berpengaruh secara positif dan signifikan terhadap keputusan menginap Hotel ini dapat dibuktikan dari adanya nilai positif pada nilai koefisien jalur yaitu sebesar 0,137 , serta nilai $t$ hitung $(2,292)$ yang lebih besar dari t tabel $(1,985)$ dan juga nilai signifikansi $\mathrm{p}$ value sebesar 0,000 yang kurang dari alpha yaitu 0,05 , Hal ini berarti selaras dengan teori yang diungkapkan oleh Kotler dan

Amstrong (2000) yang
menyatakan bahwa sejatinya
dalam memutuskan untuk membeli
suatu produk yang ditawarkan,
konumen banyak dipengaruhi oleh
ransangan pemasaran, yaitu
produk, harga, lokasi dan promosi
yang telah diterapkan perusahaan
selama ini Pernyataan ini juga
banyak didukung oleh penelitian-
penelitian terdahulu. Hasil dari
penelitian yang telah dilakukan
oleh Jumiati, Sudarwati, dan
Eganael Putra, Tarigan dan Kumar
Singh (2020), serta Sudiartha
Athar (2020). Mereka
menyebutkan pada hasil
penelitiannya bahwa terdapat
hubungan yang positif dan
signifikan antara promosi dengan
keputusan menginap yang artinya
bahwa semakin baik promosi yang
dilakukan maka akan semakin
meningkat pula keputusan tamu.

5. Pengaruh Variabel Servicescape (X2) Terhadap Keputusan Menginap (Y)

Dari hasil pengujian hipotesis (uji t) yang dilakukan pada penelitian ini, diketahui bahwa variabel servicescape berpengaruh secara positif dan signifikan terhadap keputusan tamu menginap, ini dapat dibuktikan dari adanya nilai positif pada nilai koefisien jalur yaitu sebesar 0,316, serta nilai $t$ hitung $(4,681)$ yang lebih besar dari $t$ tabel $(1,985)$ dan juga nilai signifikansi $\mathrm{p}$ value sebesar 0,000 yang kurang dari alpha yaitu 0,05 . Hal ini selaras dengan teori Harris dan Ezzeh (2018) yang menyatakan bahwa " Pada umumnya, sebelum melakukan pembelian, khususnya pada produk jasa, biasanya pelanggan akan mengevaluasi terlebih dahulu 


$\begin{array}{lll}\text { tanda-tanda untuk menilai } & \text { terhadap keputusan pembelian } \\ \text { kemampuan dan kualitas } & \text { smartphone Samsung di Kota } \\ \text { perusahaan, maka pelanggan akan } & \text { Denpasar. Dari hasil penelitian ini } \\ \text { mencari bukti berwujud yang } & \text { diketahui bahwa citra merek baik } \\ \text { memberikan informasi dan } & \text { yang telah dibangun oleh El } \\ \text { kepercayaan akan jasa yang } & \text { Royale Banyuwangi Hotel mampu } \\ \text { diterimanya, misalnya yaitu } & \text { memperbesar pengaruh promosi } \\ \text { kondisi lingkungan fisik atau } & \text { terhadap keputusan tamu } \\ \text { servicescape dari pi pemberi jasa. } & \text { menginap. Selain melihat promosi } \\ \text { Hal ini selaras dengan penelitian } & \text { yang menarik, ternyata para } \\ \text { yang telah dilakukan oleh Ali dan } & \text { responden memperhatikan citra } \\ \text { Simdani pada tahun 2017. } & \text { yang terbangun dari sebuah hotel, } \\ \text { Penelitian yang dilakukan oleh Ali } & \text { semakin baik citra yang dibangun } \\ \text { dan Simdani membuktikan bahwa } & \text { atau terbentuk, semakin membuat } \\ \text { servicescape secara parsial } & \text { masyarakat antusias terhadap } \\ \text { berpengaruh positif terhadap } & \text { sebuah promosi yang } \\ \text { keputusan menginap. Pada } & \text { dipublikasikan oleh hotel, dan } \\ \text { penelitian ini diketahui } & \text { semakin antusias masyarakat } \\ \text { servicescape berpengaruh positif } & \text { terhadap sebuah promosi yang } \\ \text { dan signifikan terhadap keputusan } & \text { dipublikasikan akan semakin } \\ \text { menginap, hal ini dicerminkan dari } & \text { meningkat pula keputusan tamu } \\ \text { keunikan estetika fasilitas sebagai } & \text { untuk menginap. }\end{array}$
salah satu keunggulan dari El Royale Hotel Banyuwangi yang dapat membuat tamu menginap puas telah menginap di El Royale Hotel Banyuwangi, ini berarti estetika fasilitas yang dimiliki oleh El Royale Banyuwangi Hotel dapat menjadi daya tarik yang sangat kuat bagi para calon tamu

6. Pengaruh Variabel Promosi (X1) Terhadap Keputusan Menginap (Y) Melalui Citra Merek (Z)

Dari hasil uji sobel dimana $\mathrm{Z}$ $=2.885>1.96$, didapatkan bahwa variabel citra merek ternyata mampu memediasi pengaruh promosi terhadap keputusan menginap di El Royale Banyuwangi Hotel. Hal ini selaras dengan penelitian yang telah dilakukan oleh Astari Armayanti dan I Made Jatra (2019). Hasil penelitian tersebut menunjukkan bahwa variabel citra merek mampu memediasi pengaruh promosi
7. Pengaruh Variabel Servicescape (X2) Terhadap Keputusan Menginap (Y) Melalui Citra Merek (Z)

Dari hasil penghitungan uji sobel dimana $Z=1,5601<1,96$ didapatkan bahwa pada penelitian ini variabel citra merek bukan sebagai variabel mediasi antara pengaruh variabel servicescape dengan keputusan menginap. Hal ini berbeda dengan penelitian yang telah dilakukan oleh oleh Benedictus Pascal Kurniawan dan Widayanto (2019) dengan judul Pengaruh Service Quality dan online Servicescape Terhadap Keputusan Pembelian melalui Brand image. Hasil yang didapatkan dari penelitian terdahulu ini adalah variable citra merek mampu memediasi pengaruh servicescape terhadap keputusan pembelian. Perbedaan hasil yang didapat bisa saja terjadi 
karena bidang yang diteliti adalah berbeda, pada penelitian terdahulu variabel yang diteliti adalah online servicescape dibidang transportasi, dimana indikator servicescape yang digunakan lebih kepada fiturfitur aplikasi virtual yang hanya digunakan sebentar, sedangkan pada penelitian ini penelitian dilakukan di sebuah hotel dan indikator servicescape yang digunakan adalah fasilitas-fasilitas yang dilihat dan dirasakan oleh pengunjung dalam waktu yang cukup lama.

\section{SIMPULAN DAN SARAN Simpulan}

Berdasarkan hasil penelitian dan analisa yang telah dilakukan mengenai pengaruh promosi dan servicescape terhadap keputusan menginap di EL Royale Hotel Banyuwangi, maka dapat ditarik kesimpulan sebagai berikut:

1. Promosi berpengaruh secara positif dan signifikan terhadap citra merek di El Hotel Royale Banyuwangi pada masa pandemi.

2. Servicescape berpengaruh secara positif dan signifikan terhadap citra merek El Hotel Royale Banyuwangi pada masa pandemi.

3. Citra merek berpengaruh secara positif dan signifikan terhadap keputusan menginap di El Hotel Royale Banyuwangi pada masa pandemi.

4. Promosi berpengaruh secara positif dan signifikan terhadap keputusan menginap di El Hotel Royale Banyuwangi pada masa pandemi.

5. Servicescape berpengaruh secara positif dan signifikan terhadap keputusan menginapdi EL Royale Banyuwangi Hotel pada masa pandemi.
6. Citra merek mampu memediasi pengaruh promosi terhadap keputusan menginap di El Hotel Royale Banyuwangi pada masa pandemi.

7. Citra merek tidak memediasi pengaruh servicescape terhadap keputusan tamu menginap di El Hotel Royale Banyuwangi pada masa pandemi.

\section{Saran}

Adapun saran yang diharapkan dapat dijadikan masukan bagi El Royale Hotel Banyuwangi, antara lain:

1. El Royale Hotel dapat memperluas sasaran direct marketing. Cakupan sasaran direct marketing bisa ditambah bukan hanya member saja, namun bisa juga bekerjasama dengan perusahaan lain dan melakukan direct marketing terhadap member perusahaan lain tersebut, seperti misalnya pemegang kartu kredit tipe tertiggi dari salah satu bank, atau member vip traveloka, dll.

2. Pada indikator Servicescape yaitu ambient condition pada item sistem pengedap suara yang baik, didapatkan 4 reponden menyatakan tidak setuju, hal ini berarti pihak EL Royale Banyuwangi Hotel harus secara konsisten melakukan maintenance dan pengecekan yag lebih detail dari seluruh fasilitas kamar sebelum kamar tamu tersebut ditempati, sehingga tidak ada celah bagi tamu untuk dapat memberikan keluhan.

\section{DAFTAR PUSTAKA}

Aal, E. A., \& Abbas, J. E. A. 2016. Assesing Social and Physical Servicescapeas Drivers of Hotel Image formation: Customers 
Prespective. Journal of Faculty of Tourism and Hotels Fayoum University, 10(1 / 2).

Ali, Stefanie Kusuma dan Dicky Larson Simdani. 2018. Analisa Pengaruh Lokasi dan Serviescape Terhadap Keputusan Menginap Konsumen Pohon Inn Hotel, jurnal Hospitality dan Manajemen Jasa : Vol. 6 No 1,pp 104-113

Armayani Astari dan I Made Jatra. 2019. Peran Brand Image Memediasi Promosi Terhadap Keputusan Pembelian Smartphone Samsung di Kota Denpasar. E-Jurnal Manajemen: Vol 8 No 8, pp 5222- 5239

Athar, Handry Sudiartha.2020. The Effect of Brand Image, Price and Promotion on The Decision Stay At Cadaka Hotel-Central Java. E-journal Binawakya : Vol 14 No 12,pp 3603-3612

Ayunisa, Fadia. 2016. Peran Servicescape Dalam Meningkatkan Hotel Image dan Revisiting Intention Pada Hotel Bintang 5.Jurnal Manajemen dan Pemasaran Jasa : Vol 9 No 2, pp 269-283

Harris,Lloyd C. and Chris Ezeh 2008.Servicesape and Loyalty Intentions:an Empiical Investigation. European Journal Of marketing. 42(3/4).390-422

Hurriyati, Ratih.2005. Bauran Pemasaran dan Loyalitas Konsumen, Bandung: Alfabeta
Keller, Kevin L. 2013. Strategic Brand Management ; Building, Measuring, and Managing Brand Equity. Fourth Edition Harlow, English : Pearson Education Inc

Kotler, Philip \& Gary Armstrong. $2000 . \quad$ Prinsip-prinsip Pemasaran, edisi keduabelas, Jilid 1. Jakarta : Erlangga

Lim, Tjong $\mathrm{Su}$ dan Anton Widio Pratomo. 2020. Pengaruh Brand Image, Persepsi Harga dan Word of Mouth Terhadap Keputusan Pembelian Konsumen The Highland Park Resort Hotel Bogor. Jurnal Ilmiah Pariwisata Kesatuan; Vol 1 No 1 . pp31-42

Lupiyoadi, Rambat. 2013. Manajemen Pemasaran Jasa Berbasis Kompetensi,Edisi 3, Jakarta: Salemba Empat

Mursid, M. 2014, Manajemen Pemasaran, Jakarta:Bumi Aksara.

Kotler, Phillip, 2002. Manajemen Pemasaran, Edisi Millenium, Jilid 1, Jakarta : Prenhalindo

Kotler, Philip and Kevin Lane Keller. 2016. Marketing Managemen, 15th Edition, Pearson Education,Inc

Kurniawan, Benedictus Pascal dan Widayanto.2018. Pengaruh Servie Quality dan Online Servicescape Terhadap Keputusan Pembelian Melalui Brand Image (Studi Kasus Pada Mahasiswa FISIP Undip 
Pengguna Jasa Transportasi

Online Go-Jek). Jurnal Ilmu

Administrasi dan Bisnis : Vol 8

No 1, pp 155-163.

Putra, Qausar Eganael , dkk. 2020.

The Impact of Marketing Mix on the Consumer Purchaase Decision in The SurabayaIndonesia Hotel Residence. SHS Web of Conference: Vol 76

Tampubolon, Emny Oktavianty. 2015. Pengaruh Promosi Terhadap Citra Oerusahaan Pada Hotel Resty Menara Pekanbaru.JOM FISIP: Vol 2 No 2, pp 1-11

Tjiptono, Fandy. 2005. Strategi PemasaranI. Edisi Kedua. Yogyakarta: Andi Offset.

Tjiptono, Fandy. 2014, Pemasaran Jasa - Prinsip, Penerapan, dan Penelitian, Yogyakarta:Andi Offset.

Zeithaml,Valarie A and Bitner.2000. Service Marketing 2nd edition : Integrating Customer Focus, New York:McGraw-Hill Inc 